\title{
IGF2BP2 wt Allele
}

National Cancer Institute

\section{Source}

National Cancer Institute. IGF2BP2 wt Allele. NCI Thesaurus. Code C147850.

Human IGF2BP2 wild-type allele is located in the vicinity of 3q27.2 and is approximately $182 \mathrm{~kb}$ in length. This allele, which encodes insulin-like growth factor 2 mRNA-binding protein 2, is involved in transport and stabilization of mRNA. Variation in the gene is associated with susceptibility to type 2 diabetes mellitus. 